\title{
INCIDENCE OF HEPATITIS-B AMONG HEALTHCARE PROFESSIONALS DUE TO MEDICAL WASTE HANDLING
}

\author{
MORSHED MG ${ }^{1}$, HOWLADER MAR ${ }^{2}$, SARDAR MH ${ }^{3}$, UDDIN MZ ${ }^{4}$, KHAN MA ${ }^{5}$
}

\begin{abstract}
The incidence of hepatitis- $B$ among health care workers due to medical waste handling has been a subject of interest. A hospital base survey was done in Chittagong Medical College Hospital (CMCH), Chittagong during the period of April 2009 through June 2009 among health care workers was done to identify the problem. All types of health care workers especially those are very much vulnerable to needle stick puncture like nurses, ward boys, cleaners, laboratory technicians and doctors were included in this study.

Total number of respondents was one hundred (sixty eight male and thirty two female). Age of the respondents ranged from 20-60 years with on average age of $24 \pm 5.5$ years. $62 \%$ of health care workers do not aware of hazards of medical waste. Only 38\% are aware of infectious medical waste. Among them only $12 \%$ learned about the hazards of medical waste from hospital authority. Rest of them is aware of this implication from personal information. All of the health care workers claimed that they have no training on medical waste handling safely. Even they do not take any protective measure. $66 \%$ of the health care workers of different service type were punctured at least once or several times. So the puncture rate was counted with special attention. Sixty percent of ward boys, $90 \%$ of nurses, $25 \%$ of doctors and $80 \%$ of laboratory technicians were punctured once or several times within their job duration.

These 5\% health care workers were HbsAg positive. Among them one ward boy, two nurses, one cleaner and one laboratory technician were infected with hepatitis B virus. All of them had history of needle stick puncture. One HbsAg positive case was excluded from this study because of history of blood transfusion. Waste sharps are considered highly infectious medical waste causing hepatitis $B$ frequently.
\end{abstract}

Key words: Medical waste, occupational risk, hepatitis $B$.

\section{Introduction:}

Health-care waste is a reservoir of potentially harmful microorganisms ${ }^{1}$, which can infect hospital patients, health-care workers and the general public ${ }^{2}$. Other potential infectious risks include the spread of, sometimes resistant, microorganisms from health-care establishments into the environment ${ }^{3}$. These risks have so far been only poorly investigated.

Medical waste poses the potential problems to health care workers, to waste handlers and to the environment ${ }^{4,5}$. Among the biohazards the occupational risks posed by hepatitis B virus (HBV) and HIV are well documented. ${ }^{6}$

In a study, dealing with a health care setting, the federal centers for disease control in United States has estimated that 12,000 health care workers, whose jobs entail exposure to blood become infected with hepatitis B each year that 500-600 of them are hospitalized as a result of that infection, and that 700-1,200 of those infected become carriers ${ }^{7,} 8$. In United States annual number of HBV infections caused by occupational injuries from sharps among

1. Assistant Registrar, Department of Medicine, Dhaka Medical College Hospital, Dhaka.

2. Assistant Professor, Department of Medicine, Dhaka Medical College, Dhaka.

3. Associate Professor, Department of Medicine, Dhaka Medical College, Dhaka.

4. Post graduate trainee, BSMMU, Dhaka.

Correspondence: Dr. Md. Goalm Morshed. 
waste management workers is $1-15^{9,10}$. But there was no such type of data in Bangladesh perspective. To investigate the risk of HBV infections among health care professionals due to medical waste handling this study was carried out.

\section{Materials AND Methods:}

Type of study: Descriptive \& Cross-sectional in nature.

Place of study: Chittagong Medical College Hospital (CMCH).

Study population: Nurses, doctors, laboratory technicians, cleaners working in $\mathrm{CMCH}$.

Inclusion criteria: 1 .Working as a medical professional for at least 20 weeks.

Exclusion criteria: 1. Known HbsAg positive patient before starting this job. 2. Having any history of unsafe blood transfusion 3. Parenteral drug abusers, 4. Taking acupuncture treatment 5. Having spouse of hepatitis B patient, 6. Those refused to take part in this study

Sample size: 100

Sample technique: Convenience sampling.

Period of study: $1^{\text {st }}$ April 2009- 30 th June 2009.

Data collection instrument: Prepared questionnaire.

Methods of data collection: A pre structured survey form is prepared before enrollment of patients. Data were collected by interview per questionnaire.

Serological test : HbsAg was done in selected cases those fulfilled inclusion criteria. The blood was collected by the expert clinical pathologist technician working in hospital. Five $\mathrm{ml}$ blood was collected in a sterile way and sample was immediately sent to pathology department for ELISA test for confirmation. The unique ID was given in pathological slip which was consistent with the survey form. Reports are collected by the corresponding author himself and later analyzed.

Data analysis: After collection, data were checked and verified. Then data were analyzed manually with the help of a calculation, according to the objectives of the study.

\section{Results:}

A total of 100 (68 male, 32 female) health care professionals were selected randomly. Age of the cases ranged from 20-60 years with an average of $24 \pm 5.5$ years. Maximum number of professionals $52(52 \%)$ was in the age range 41-50 years (table I). Sixty eight percent were male and $32 \%$ were female respondent. Seventy eight percent were married. Seventy four percent total healthcare professionals are from poor socio-economic condition (Table-II). Seventy four percent cases were in the income group of monthly 2000-5000 taka and 26\% having income of more than 5000 but less than 10000 taka monthly.(table III).

\section{Table-I}

Distribution of respondent by age $(N=100)$

\begin{tabular}{lcc}
\hline Age limit (yrs.) & No. of cases & Percentage \\
\hline $30-40$ & 28 & $28 \%$ \\
$41-50$ & 52 & $52 \%$ \\
$51-60$ & 24 & $24 \%$ \\
\hline Total & 100 & $100 \%$ \\
\hline
\end{tabular}

Table-II

Distribution of respondent by religion $(N=100)$

\begin{tabular}{lcc}
\hline Religion & No. of cases & Percentage \\
\hline Muslim & 28 & $28 \%$ \\
Hindu & 68 & $68 \%$ \\
Buddhist & 4 & $4 \%$ \\
Christian & 2 & $2 \%$ \\
\hline
\end{tabular}

Table-III

Distribution of incident by socioeconomic status(n-100)

\begin{tabular}{lcc}
\hline $\begin{array}{l}\text { Monthly income } \\
\text { (BDT) }\end{array}$ & No. of cases & Percentage \\
\hline $2000-5000$ & 74 & $74 \%$ \\
$5000-10000$ & 26 & $26 \%$ \\
$>10000$ & 0 & $00 \%$ \\
\hline
\end{tabular}

Sample individuals are taken from different clusters (Table-IV) of health professionals (10 $\%$ are taken from ward boy, 35\% from nurse, $20 \%$ from doctor, $25 \%$ from cleaner and $10 \%$ from laboratory technician). None of them are 
working (Table-V) in this profession less than 20 weeks (38\% have $2-10$ years job duration, $34 \%$ have $11-20$ years job duration, $23 \%$ have 21-30 years job duration and 5\% have more than 30 years job duration). Sixty two percent of health care workers do not aware of hazards of medical waste. Only $38 \%$ are aware of infectious medical waste (Table-VI).

Table-IV

Distribution of respondent by category of service $(N=100)$

\begin{tabular}{lcc}
\hline Category of service & No. of cases & Percentage \\
\hline Ward boy & 10 & $10 \%$ \\
Nurse & 35 & $35 \%$ \\
Doctor & 20 & $20 \%$ \\
Cleaner & 25 & $25 \%$ \\
Laboratory Technician & 10 & $10 \%$ \\
\hline
\end{tabular}

Table-V

Distribution of respondent by duration of service $(N=100)$

\begin{tabular}{lcc}
\hline Years & No. of cases & Percentage \\
\hline $2-10$ & 38 & $38 \%$ \\
$11-20$ & 34 & $34 \%$ \\
$21-30$ & 23 & $23 \%$ \\
$31+$ & 5 & $5 \%$ \\
\hline
\end{tabular}

Table-VI

Distribution of respondent by knowledge regarding infectious medical waste ( $N-100)$

\begin{tabular}{lcc}
\hline $\begin{array}{l}\text { Category of } \\
\text { service }\end{array}$ & $\begin{array}{c}\text { No. of } \\
\text { respondent }\end{array}$ & $\begin{array}{c}\text { No. of } \\
\text { respondent } \\
\text { having knowledge } \\
\text { regarding infectious } \\
\text { medical waste }\end{array}$ \\
\hline Ward boy & 10 & 3 \\
Nurse & 35 & 12 \\
Doctor & 20 & 16 \\
Cleaner & 25 & 2 \\
Laboratory & 10 & 5 \\
Technician & & 38 \\
Total & 100 & \\
\hline
\end{tabular}

Sixty six percent of health care workers of different service types were punctured at least once or several times (Table VII).
Table-VII

Distribution of respondent by instrumental puncture $(N-100)$

\begin{tabular}{lccc}
\hline $\begin{array}{l}\text { Category of } \\
\text { service }\end{array}$ & $\begin{array}{c}\text { No. of } \\
\text { respondent }\end{array}$ & $\begin{array}{c}\text { No. of } \\
\text { puncture }\end{array}$ & $\begin{array}{c}\% \text { of } \\
\text { puncture }\end{array}$ \\
\hline Ward boy & 10 & 6 & $60 \%$ \\
Nurse & 35 & 32 & $90 \%$ \\
Doctor & 20 & 5 & $25 \%$ \\
Cleaner & 25 & 12 & $48 \%$ \\
Laboratory Technician & 10 & 8 & $80 \%$ \\
\hline
\end{tabular}

One ward boy, two nurses, one cleaner and one laboratory technician were infected with hepatitis B virus (Table-VIII). A total of $5 \%$ of healthcare worker was infected with hepatitis B.. Their serological test for HbsAg was positive.

Table-VIII

Distribution of respondent by hepatitis $B$ infection $(N=100)$

\begin{tabular}{lcc}
\hline $\begin{array}{l}\text { Category of } \\
\text { service }\end{array}$ & $\begin{array}{c}\text { No. of } \\
\text { respondent }\end{array}$ & $\begin{array}{c}\text { No. of } \\
\text { hepatitis } \\
\text { B infection }\end{array}$ \\
\hline Ward boy & 10 & 1 \\
Nurse & 35 & 2 \\
Doctor & 20 & - \\
Cleaner & 25 & 1 \\
Laboratory Technician & 10 & 1 \\
\hline Total & 100 & 5 \\
\hline
\end{tabular}

\section{Discussion:}

In this study most of the respondents were in the age group $41 \mathrm{t}$ o50 yrs. This is correlated with the similar study done in USA. ${ }^{7,8}$ Seventy percent married respondent were carefully investigated regarding their spouse of hepatitis B patient.They were enquired about housing, sanitation and personal hygiene. The income generation of these younger age group were not consistent with similar studies in USA ${ }^{8}$. This is due to economic variability of different countries especially in developing countries. Sixty two percent of health care workers do not aware of hazards of medical waste. Only 38\% are aware of infectious medical waste. Among them only $12 \%$ said, they learned about the hazard of medical waste from hospital authority. Rest of them is aware of this implication from personal information. All of the health care workers claimed that they have no training on 
medical waste handling safely. Even they do not take any protective measure. The principles of waste management were not trained to these employees which is unusual. The employee should have training with quality regarding waste management before their activity initiated in professional way. ${ }^{10,11}$ The 66 percent respondent were victims of needle puncture in this study. This is remarkably high and not correlated with similar studies in USA ${ }^{7,8}$. Except doctors and nurses all other medical waste workers never know that they used to handle medical waste disposed by the patient of hepatitis B. So they handle it carelessly without taking any protective measures. Sometimes they were punctured but always it was negligible to them. All of them had history of needle stick puncture which indicate the common mistakes of negligence of common procedure in a hygienic way. The respondent with needle stick injury was $\mathrm{HbsAg}$ positive. One HbsAg positive case was excluded from this study because of history of emergency blood transfusion which was not properly screened.

Health care workers those were parenteral drug abusers, taking acupuncture treatment, having spouse of hepatitis B patient and having any history of unsafe blood transfusion were excluded from this study. So the total number of victims of $\mathrm{HbsAg}$ is even undermined in this study. A total $5 \%$ health worker suffering from infected waste thus may be even higher if all the possible causes are searched for. Even among medical waste handlers hepatitis B infection is higher in our country than other same study conducted in Libya which was $2.3 \%{ }^{12}$. where General concept regarding waste management was very poor in this study (38\%). So appropriate knowledge based training and workshops may improve the scenario in hospital settings. Nurses are prone mostly for puncture through needles. The quality testing and quality assurance both is to be involved in nursing to eliminate the gross negligence of self in waste dealing.

\section{Conclusion:}

Medical waste particularly infectious medical wastes are potential depot of numerous microbes, which implicates health care workers and also public health. Due to needle stick puncture infectious disease like AIDS, Hepatitis B \& C can be transmitted to the health care workers ${ }^{11}$. In our country, among these infectious diseases hepatitis B has much more potentiality to be transmitted to the health care worker through puncture or any way contact of body fluid or blood. This study showed that $5 \%$ of health care workers are infected with hepatitis B due to medical waste handling. So protective measure should be taken as well as hepatitis B immunization should be mandatory to the health care workers. Large scale prospective study is also recommended to measure the extent of risks of HBV infection among health care professionals, as in our settings they have to often work without personal protective equipment (PPE).

\section{References:}

1. Ayliffe GAJ et al, eds: Control of Hospital Infection: a Practical Handbook, $3^{\text {rd }}$ ed. London, Chapman \& Hall Medical press, 1992.

2. Babich H. Reproductive and Carcinogenic health risks to hospital personnel from chemical exposure. A literature review, Environmental Health, 1985; 48(2): 52 to 56 .

3. Saifullah ASM, Jabber SMA, Morshed MG, Sobhani $\mathrm{ME}$. An assessment of generation of medical wastes in a public hospital of a tertiary level medical institute in Bangladesh. Khulna University Studies, 2006; 7(2): 7-11.

4. Bouvet E, Groupe demEtude surleRisqué de Exposition au Sang. [Risk for health professionals of infection with human immunodeficiency virus. Current Knowledge and developments in preventive measures.] M'decine et maladies infectieuses, 1993; 23: 28-33.

5. Canadian Society of Hospital Pharmacy (1981), Guidelines for the handling of hazardous Pharmaceuticals. Toronto. 1981.

6. Cass Y, Musgrave CF. Guidelines for the safe handling of excreta contaminated by cytotoxic agents. Am J Hosp Phar, 1992; 49: 1957-8.

7. Dunsmore DJ. Safety measures for use in out breaks of communicable diseases. Geneva, World Health Organization. 1986.

8. Irish Association for Nurses in Oncology, Guidelines for the safe handling and administration of cytotoxic drugs. Dublin. 1990.

9. London Waste Regulation authority, The London Waste Regulation authority's Clinical Waste Guidelines, $2^{\text {nd }}$ ed. London. 1994.

10. Ministry of health, Handbook of hazardous health care waste management in 10-bed and 30-bed community hospitals, Bangkok. 1995.

11. Thofern $\mathrm{E}$, Botzenhart $\mathrm{K}$, Hygiene und Infektion im Krankenhaus, [hygiene and Infection in the Hospital] Stuttgart, Fischer. 1993.

12. Franka E, El-Zoka AH, Hussein AH, Elbakosh MM, Arafa AK, Ghenghesh KS. Hepatitis B virus and hepatitis $\mathrm{C}$ virus in medical waste handlers in Tripoli, Libya. J Hosp Infect. 2009; 72(3): 25861. 